\title{
Influence of panicle fungicides and harvest schedules on sorghum seed quality under humid tropical conditions in Puerto Rico'
}

\author{
Paul R. Hepperly, Claudio Feliciano, and \\ Antonio Sotomayor-Rios ${ }^{2}$
}

\begin{abstract}
Fungicide applied directly to developing panicles of the sorghum culfivars TAM 428 and Pioneer $\mathbf{8 4 6}$ substantially reduced seed quality losses caused by fungal infections at harvest at physiological maturity (pm) and in delayed harvesis under warm humid tropical conditions in Puerto Rico. With four sprays of benomyl plus captan, germination losses 2 weeks after pm were $30.3 \%$; for nonsprayed plots $75.3 \%$. Compared to a four spray schedule and no sprays, one spray 3 weeks after boot stage gave approximately $75 \%$ control of germination losses at 2 weeks after pm. Observed losses in seed appearance and germinability were strongly associated with decreases in seed density, increases in harvest delay, and reductions in fungicide applications. All seedlots except those from plants sprayed 2 or 4 times and which were harvested at either pm or 1 week later, produced unaceeptable germination rates (less than $80 \%$ ). Under warm humid tropical environment, local production of high quality sorghum seeds for planting depended on both timely harvesting and chemical control methods. Losses in seed densify over delayed harvest were direct economic losses. Twenty percent loss was noted after 2 weeks and 10\% after 1 week. The best fungicide control treatment yielded $5 \%$ denser seed at pm than nonprotected counterparts at the same harvest.
\end{abstract}

\section{INTRODUCTION}

Williams and Rao (7) recently reviewed the status of sorghum seed molds. During the 1960's, 1970's and 1980's there has been an increasing awareness of the losses in sorghum seeds because of fungal infection. Tarr (5) in a compendium of sorghum diseases dismissed sorghum seed molds as minor diseases. Williams and Rao (7) suggest seed mold severity on sorghum has increased of late because of inereases use of photoperiod insensitive cultivars which mature under humid periods. According to these authors, photoperiod sensitive traditional sorghum varieties avoid humid conditions during their seed filling.

Aecording to Williams and Rao (7), sorghum seed molds will be controlled by increasing genetic resistance and studies on how seed molds

'Manuscript submitted to Editorial Board September 30, 1985.

2The first two authors are Associate Professor and Former Graduate Research Assistant, respectively, Department of Crop Protection, College of Agricultural Sciences, Mayagizez, P. R. 00708. Third author is a Supervisory Research Agronomist, USDA, TARS, Mayagüez, P. R. 00709. 
spread and alternative control methods are unwarranted. Genetic resistance to sorghum seed molds may be related to negative factors. A good example of this is the presence of astringent factors, such as tannins, which reduce sorghum digestibility (8), Other negative factors possibly related to resistance to a wide range of seed molds may be impermeability of sorghum seeds and small seed size. Before intelligent decisions can be made on the value of control measures, better information of the extent of losses, costs of different control methods, and value of the commodity must be integrated.

The purpose of this research was to determine the efficacy of chemical control of seedborne fungi under variable spray and harvest schedules in cultivated sorghum under humid tropical conditions in Puerto Rico.

\section{MATERIALS AND METHODS}

The experiment was conducted in the Mayaguiez experimental field of the USDA Tropieal Agriculture Research Station (TARS), USDA, ARS, S\&E on a Consumo clay (Dystropeptic Tropudults). The farm is located about $100 \mathrm{~m}$ above sea level with ambient temperatures ranging from 22 to $25^{\circ} \mathrm{C}$. The soil was of the Consumo-Humatas association characterized by high acidity ( $\mathrm{pH} 4.7$ ), strong leaching, sticky clayey and plastic texture of low to moderate fertility. Fields were planted in February 1980 and harvested in May and June of 1980. Warm humid conditions prevailed throughout sorghum reproductive and harvest stages. The average monthly precipitation for Mayagüez in May and June are 215 and 216 $\mathrm{mm}$, respectively.

The experimental design was a randomized complete block with four replications. Main plots consisted of four fungicide regimes. These were: 1) nonsprayed (control); 2) one spray, 3 weeks after boot stage; 3 ) two sprays, one at boot stage and another 3 weeks later; and 4) four sprays, starting at boot stage and continuing on a weekly interval. Plots consisted of 4 rows spaced $1.5 \mathrm{~m}$ apart. Main plots were split according to schedule. Harvests were: 1) at physiological maturity (pm); 2) 1 week after pm; and 3) 2 weeks after pm. Seed samples were analyzed for 1) frequency of elean seeds (seeds with visible fungal signs), 2) seed density, 3) frequency of seed germination and 4) frequency of seedborne microorganisms.

Fungicides were diluted in water and applied directly to the panicles with a Handi Backpack Hand Spray Pump (25 1 capacity) ${ }^{3}$ at 20 to 30 lb/in ${ }^{2}$ pressure. Benomyl (Benlate $50 \mathrm{WP}^{\mathrm{RT}}$ E. I. Du Pont de Nemours)

3 Trade names in this publication are used only to provide specific information. Mention of a trade name does not constitute a warranty of equipment or materials by the Agricultural Experiment Station of the Unviersity of Puerto Rico, nor is this mention a statement. of preference over other equipment or materials. 
and Captan (Captan $50 \mathrm{WP}^{\mathrm{RT}}$, Stauffer Chemical) ${ }^{3}$ were tank mixed and applied at a rate of $0.5+0.5 \mathrm{~kg}$ a.i./ha for each spray.

After harvest, approximately 200 seeds were randomly sampled from each subplot. One hundred fifty seeds from each were observed under the dissecting microscope to detect seed with visible growth of fungi. After determination of visual seed quality 125-seed samples were weighed and their density calculated. Fifty seeds per subplot were analyzed on culture media for seed germination and infection.

Seed density was determined by weighing 125 -seed samples and then determining their volume displacement in a calibrated pipette partially filled with $95 \%$ ethanol. From the seed weight and volume measurements, density was calculated and expressed in grams of sorghum seed over cubic centimeters of volume (4).

Seed germination and infection were determined by submerging for 4 minutes in $0.5 \% \mathrm{NaOCl}(10 \%$ Clorox). Seeds were then dried aseptically under a sterile laminar flow hood and planted in potato dextrose agar with 5 seeds per $9 \mathrm{~cm}$ plate. Plates were incubated at $25^{\circ} \mathrm{C}$ for 7 days; then seed germination and fungi were recorded.

\section{RESULTS AND DISCUSSION}

Table 1 summarizes the effects of panicle applications of benomyl and captan on seed infection in TAM 428 and Pioneer 846 sorghums. One fungicide application 3 weeks after boot state reduced the incidence of

TABLE 1.-The influence of benomyl phus captan sprays applied to the panicles of TAM 428 and Pioneer 846 Sorghums on seedborne microflora over three havest dates under hamid tropical conditions in Mayagüez, Puerto Rico

\begin{tabular}{|c|c|c|c|c|}
\hline \multirow{3}{*}{ Microorganisms } & \multicolumn{4}{|c|}{ Percentage inciclence } \\
\hline & \multicolumn{4}{|c|}{ Numbers of applications ${ }^{9}$} \\
\hline & 0 & $1^{2}$ & $2^{3}$ & $4^{4}$ \\
\hline $\begin{array}{l}\text { Altemaria spp. } \\
\text { Colletotrichumm }\end{array}$ & $4^{5}$ & 39 & 37 & 15 \\
\hline graminicola & 23 & 3 & 0 & 0 \\
\hline $\begin{array}{l}\text { Curvularia spp. } \\
\text { Fusavium }\end{array}$ & 22 & 39 & 36 & 20 \\
\hline moniliforme & 43 & 28 & 5 & 0 \\
\hline Nigrospora oryzae & 23 & 5 & 0 & 0 \\
\hline Phoma spp. & 2 & 2 & 0 & 0 \\
\hline Other Fungi & 13 & 12 & 12 & 5 \\
\hline Bacteria & 5 & 3 & 2 & 18 \\
\hline
\end{tabular}

Applied at $0.5+0.5 \mathrm{~kg}$ a.i./ha per application.

2 Three weeks after boot stage.

3 At boot stage and 3 weeks later.

- Starting at boot stage with a weekly interval.

${ }^{5}$ Means based on 2450 -seed samples which were surface disinfected and plated on sterile PDA. 
Fusarium moniliforme, the dominant seed-borne fungus when no fungicide was applied. With a single application of benomyl and captan, Curvularia and Altemaria species replaced $F$. moniliforme as the dominant fungi; Colletotrichum graminicola and Nigrospora oryzae were more sensitive than $F$. moniliforme to the fungicide applications. A sole application of fungicide reduced their incidence from over $20 \%$ each to less to $5 \%$ each. A low incidence of bacteria (less than $5 \%$ ) was found in sorghum receiving 2 or fewer fungicide applications. With four fungicide applications, $18 \%$ seedborme bacteria was noted. Table 2 shows the effect of harvest stage and fungicide treatments on sorghum seed germination. Acceptable seed germination ( $80 \%$ or more) was found only when sorghums were harvested at pm or 1 week thereafter and when they were sprayed with fungicide two or four times during sorghum reproductive stages. Harvest stage appeared to affect germination losses more strongly than fungicide treatments.

Table 3 shows the effect of harvest stage and fungicide treatments on the incidence of seed without visible fungi (clean seed). Data on clean seed and germination appeared highly correlated. High visual seedlot quality ( $80 \%$ or more clean seed) was found only on seeds harvested from plants just reaching physiological maturity and receiving fungicide treatments during their reproductive stages. Clean seed incidence was more sensitive than seed germination in showing the effect of delayed harvest and fungicide treatments.

TABLE 2,-Germination percentage of TAM 428 and Pioneer 846 Sorghum seeds under variable schedules of havest and fungicide application' under humid tropical conditions in Mayagiüez, Prerto Rico

\begin{tabular}{|c|c|c|c|c|}
\hline \multirow{3}{*}{ Spray applications } & \multicolumn{3}{|c|}{ Percentage germination } & \multirow{3}{*}{$\begin{array}{l}\text { Spray } \\
\text { regimen } \\
\text { mean }\end{array}$} \\
\hline & \multicolumn{3}{|c|}{ Harvest stage ${ }^{2}$} & \\
\hline & PM & +1 & +2 & \\
\hline None & $74^{3}$ & 50 & 22 & 48.7 \\
\hline Onet & 79 & 76 & 39 & 64.7 \\
\hline Two $0^{5}$ & 87 & 81 & 47 & 71.7 \\
\hline Four ${ }^{4 i}$ & 89 & 84 & 62 & 78.3 \\
\hline \multicolumn{5}{|l|}{$\begin{array}{l}\text { Harvest } \\
\text { date }\end{array}$} \\
\hline mean & 82,3 & 72.8 & 42.5 & \\
\hline
\end{tabular}

${ }^{1}$ Panicle application of benomyl + captan at $0.5+0.5 \mathrm{~kg} \mathrm{a.i./ha}$.

${ }^{2}$ Harvest at physiological maturity $(\mathrm{pm})$ and one $(+1)$ and two $(+2)$ weeks thereafter.

${ }^{3}$ Means based on 850 -seed samples.

4 Spray at 3 weeks after boot stage.

s Sprays at boot stage and 3 weels thereafter.

- Sprays at boot stage and at a weekly interval thereafter. 
TABLE 3.-Clean seed" incidence as influenced by variable schedules of fungicides application ${ }^{2}$ and harvesting in TAM 428 and Pioneer 846 sorghum under humid tropical conditions in Mayagüez, Puerto Rico

\begin{tabular}{|c|c|c|c|c|}
\hline \multirow{3}{*}{ Application } & \multicolumn{3}{|c|}{ Clean seed percentage } & \multirow{3}{*}{$\begin{array}{l}\text { Spray } \\
\text { regimen } \\
\text { mean }\end{array}$} \\
\hline & \multicolumn{3}{|c|}{ Harvest date ${ }^{2}$} & \\
\hline & PM & +1 & +2 & \\
\hline None & $74^{4}$ & 31 & 8 & 37.7 \\
\hline $\mathrm{One}^{t}$ & 80 & 64 & 0 & 48.0 \\
\hline Two 6 & 82 & 67 & 24 & 57.7 \\
\hline Four ${ }^{z}$ & 97 & 72 & 57 & 75.3 \\
\hline \multicolumn{5}{|l|}{$\begin{array}{l}\text { Harvest } \\
\text { date }\end{array}$} \\
\hline mean & 83.3 & 58.5 & 22.5 & \\
\hline
\end{tabular}

${ }^{1}$ Clean seeds are those free of visible fungal growth.

2 Benomyl + eaptan at $0.5+0.5 \mathrm{ka}$ a.i.ha per application.

${ }^{3}$ At physiological maturity $(\mathrm{pm})$ and one $(+1)$ and two $(+2)$ weeks thereafter.

4 Means based on 8100 -seed samples.

5 Three weeks after boot stage,

${ }^{6}$ At boot stage and 3 weeks thereafter.

${ }^{7}$ Starting at boot stage on a weekly interval.

Table 4 shows the losses in seed germination and clean seed incidence under variable harvest and fungicide schedules. Clean seed losses were more pronounced than losses in seed germinability.

Seed density was highly correlated with seed germination and clean seed values (table 5, fig. 1A and 1B). Losses in seed density in delayed harvest constitute direct economic losses. Under our conditions, these losses were over $20 \%$ in a 2 week harvest delay without fungicide, and less than $5 \%$ after the same delay when four fungicide applications were made during sorghum reproductive stages. Losses in seed density between a treatment of four fungicide applications at pm and a nonsprayed treatment was $5 \%$. This difference rose to $10 \%$ and $20 \%$ for harvest 1 and 2 weeks after $\mathrm{pm}$, respectively.

\section{DISCUSSION}

The changes of seed microflora with fungicide applications can be best explained on the basis of selectivity of benomyl (6). Although benomyl is highly active against many imperfect fungi, for example $F$, moniliformem, C. graminicola, and Nigrospora oryzae, it is particularly ineffective against some porosporic dematiaceous hyphomycetes, including species of Alternaria and to a lesser degree Curvularia (2).

Alternaria spp. do not appear to be greatly inhibitory to sorghum seed germination although they mar seed appearance (3). Curvilaria spp., on the other hand, markedly reduce both seed appearance and viability. In areas where Curvularia and Alternamia are prevalent, ben- 
TABLE 4.-Losses in TAM 428 and Pioner 840 sorghum in seed germination and clean seed incidence as influenced by variable schedules of fungicide application and harvesting under varm humad conditions in Mayagëz, Puerto Rico

\begin{tabular}{|c|c|c|c|c|c|c|}
\hline \multirow[b]{4}{*}{ Applieation $^{3}$} & \multicolumn{6}{|c|}{ Percentage losses } \\
\hline & \multicolumn{6}{|c|}{ Harvest ${ }^{2}$} \\
\hline & \multicolumn{2}{|c|}{ PM } & \multicolumn{2}{|c|}{+1} & \multicolumn{2}{|c|}{+2} \\
\hline & $G^{4}$ & $\mathrm{cs}^{t}$ & $\bar{G}$ & $\mathrm{Cs}$ & q & $\mathrm{CS}$ \\
\hline None & 16.2 & 23.7 & 43.8 & 68.0 & 75.3 & 92.5 \\
\hline One ${ }^{6}$ & 11,2 & 17.5 & 14.5 & 34.0 & 56.2 & 100.0 \\
\hline Two $o^{7}$ & 2.3 & 15.5 & 8.8 & 30.0 & 47.2 & 75.3 \\
\hline Four ${ }^{8}$ & 0.0 & 0.0 & 5.6 & 25.8 & 30.3 & 41.2 \\
\hline
\end{tabular}

${ }^{1}$ Percentage $=\frac{\text { highest mean schedule value - sample mean schedule value }}{\text { highest mean schedule value }} \times 100$

Harvest at phystological maturity (pm) and one $(+)$ and two $(+2)$ weeks thereafter

${ }^{a}$ Benomyl + captan $0.5+0.5 \mathrm{~kg}$ a.i./ha/spray applied as a directed spray on developing panicles.

$+\mathrm{G}=$ seed gemination.

${ }^{5} \mathrm{CS}=$ clean seed.

${ }^{5}$ One spray 3 weeks after boot stage.

'Sprays at boot stage and 3 weeks thereafter.

"Sprays at boot stage and at a weekly interval thereafter.

TABLw 5. Sorghum seed density ${ }^{1}$ as influenced by fungicide ${ }^{2}$ schedules in TAM 428 and Pioneer 846 sorghum under hamid tropical in Mayagiez, Prerto Rico

\begin{tabular}{lcccc}
\hline \multirow{2}{*}{$\begin{array}{c}\text { Fungicide } \\
\text { applieation }\end{array}$} & \multicolumn{3}{c}{\begin{tabular}{c} 
Mean seed density $\left.\mathrm{g} / \mathrm{cm}^{\mathrm{g}}\right)^{3}$ \\
\cline { 2 - 4 }
\end{tabular}} & \multicolumn{3}{c}{ Harvest date } & $\begin{array}{c}\text { Funpieide } \\
\text { application } \\
\text { mean }\end{array}$ \\
\cline { 2 - 4 } & $\mathrm{PM}$ & +1 & +2 & \\
\hline None & 1.27 & 1.22 & 1.10 & 1.20 \\
One & 1.29 & 1.20 & 1.21 & 1.23 \\
Two & 1.30 & 1.29 & 1.25 & 1.28 \\
Four & 1.31 & 1.27 & 1.28 & 1.29 \\
Harvest & & & & \\
date & 1.29 & 1.25 & 1.21 & \\
mean & & & \\
\hline
\end{tabular}

1 Density expressed in g/cm ${ }^{3}$ calculated by ethanol displacement according to Ross and Kofoid 1978.

${ }^{2}$ Benomyl + eaptan applied at $0.5=0.5 \mathrm{~kg}$ a.i./ha per application. Applications were: 1) 3 weeks after boot stage; 2) at boot stage and 3 weeks thereafter; or 3 ) at boot stage and at a weekly interval thereafter.

${ }^{3}$ Means based on 8125 -seed samples.

- Harvest were at physiological maturity $(\mathrm{pm})$, at pm plus 1 week $(+1)$ and at pm plus 2 weeks $(+2)$. 
J.Agric. Univ. P.R. vol. 71, NO. 1, JANUARY, 1987

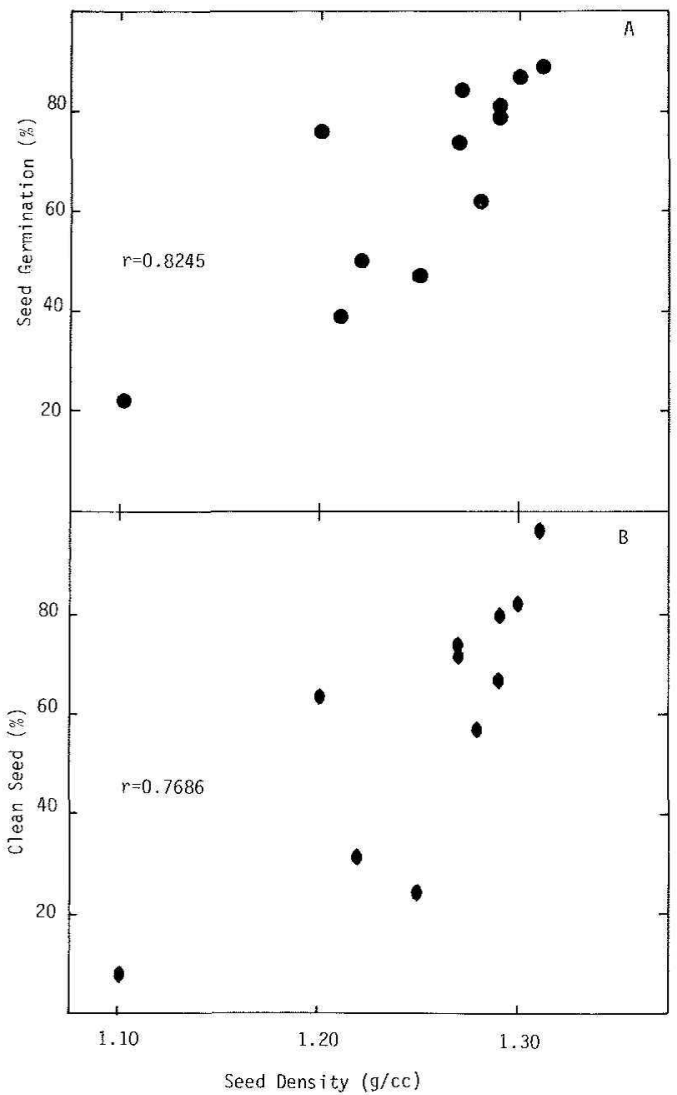

FrG. 1.-Correlations of sorghum seed density with A) Seed germination and B) Clean seed percentages in TAM 428 and Pioneer 846 sorghum grown under variable harvest and fungicide regimes under humid tropical condition in Mayagüez, Puerto Rico. Seed density, clean seed, and seed germination values are means based on eight 125-, 100-, and 50-seed samples, respectively. 
zimidazoles alone will not be effective in controlling seed mold. Under these conditions, fungicide mixtures or rotations featuring increased dosages of suitable organic protectant fungicides will be needed in chemical control of sorghum seed molds. There is a great potential among sterol inhibitor fungicides to control sorghum seed molds at low rates (6). Both of the above mentioned strategies deserve further investigation. Furthermore, besides offering the prospective of increasing control they also may prevent development of benzimidazole resistant populations which are common when benzimidazoles are repeatedly used as a sole chemical control method (1).

Seed germination and clean seed data indicate that the production of high quality seed under warm humid tropical environments is not easy. A combination of timely harvest and fungicide application was necessary for producing acceptable planting seeds with eurrently available commercial sorghums under our conditions. Increased genetic resistance could help reduce the need for fungicides and early harvesting to produce high viability planting seed in the warm humid tropics. Because of the high levels of losses by seed molds and the importance of high quality seed for planting, fungicides are probably warranted in warm humid areas where high quality locally adapted sorghum seeds cannot be imported. The economics of sorghum seed mold control measures deserves more detailed study for both planting seed and grain.

Sorghum seed density loss was directly related to seed yield losses and was highly correlated with losses in seed viability and visual appearance of sorghum. The economic impact of quality is difficult to assess. On the other hand, yield losses represent direct losses to producers. Seed density directly reflects yield losses and is highly associated with seedlot quality. For these reasons, seed density should be much more widely considered in grading and quality studies.

\section{RESUMEN}

La influencia de aplicar fungicidas a la panoja y de los esquemas de aplicación sobre la calidad de la semilla del sorgo bajo condiciones tropicales húmedas

Los fungicidas aplicados directamente a las panojas de las cultivares de sorgo TAM 428 y Pioneer $\mathbf{8 4 6}$ redujeron sustancialmente las pérdidas en la calidad de la semilla causadas par la infección por hongos. Este efecto se defectó al cosechar las panojas en su madurez fisiológica y tardiamente bajo condiciones cálidas y húmedas en Puerto Rico. Al cosechar las panojas de sorgo 2 semanas después de la madurez fisiológica y mediante cuatro aspersiones de una mezcla de benomil y captano, se detectó una pérdida de $\mathbf{3 0 . 3} \%$ en germinación en las parcelas asperjadas y $\mathbf{7 5 . 3} \%$ de pérdida en germinación en las parcelas no asperjadas. Una aspersión 3 semanas después de aparecer la panoja controló $75 \%$ de la pérdida en germinación 
que controló el programa de cuatro aspersiones. Las pérdidas en apariencia y germinación de la semilla estaban altamente asociadas con disminuciones en la densidad de la semilla, la cosecha tardía y reducciones en el número de aplicaciones con fungicida. Todos los lotes de semilla, excepto los provenientes de plantas que se asperjaron 2 ó 4 veces y que se cosecharon en su madurez fisiológica o una semana después, mostraron germinaciones inaceptables (menos de $80 \%$ ). Bajo condiciones cálidas y húmedas, la producción local de semillas de sorgo de alta calidad para la siembra depende de dos factores principales: cosechar la semilla a tiempo y aplicar fungicidas. Para los productores de grano, las pérdidas en densidad de la semilla por infección por hongos causa un daño económico. Al cosechar las semillas en madurez fisiológica, cuatro aplicaciones de fungicidas aumentaron la densidad de las semillas en $5 \%$. Al cosechar tardíamente a una $y$ dos semanas después de la madurez fisiológica, se registraron pérdidas en la densidad de semillas de 10 y $20 \%$, respectivamente.

\section{LITERATURE CITED}

1. Delp, C. J., 1980. Coping with resistance to plant disease control agents. Plant Disease $64(7): 652-57$.

2. Hepperly, P. and A. Sotomayor-Ríos, 1980. Evaluation of seed treatment fungicides for determining sorghum seed quality losses associated with seedborne fungi in Puerto Rico, 1979. Fung, and Nemat. Tests 35; 191.

3. — C. Feliciano and A. Sotomayor-Ríos, 1982. Chemical control of seedborne fungi of sorghum and their association with seed quality and germination in Puerto Rico. Plant Dis. 66: 902-04.

4. Ross, W. M. and K. D. Kofoid, 1978. Determining 1,000 seed weight in grain sorghum. Crop Sei. 18 (3): 507-09.

5. Tarr, S. A. J., 1962. Diseases of Sorghum, Sudangrass, and Broom Corn. CMI, Kew, Surrey, England.

6. Thompson, W. T., 1980. Agricultural Chemicals. IV. Fungicides. Thompson Publications, Fresno, California.

7. Williams, R. J. and K. N. Rao, 1979. A review of sorghum grain mold. ICRISAT, Hyderabad, India. (mimeograph).

8. York, J. O., T. S. Nelson, O. T. Stallup and R. W. Bullard, 1982. Dry matter digestibility in purple testa sorghum: pages 1-9 in Proc. 37th Ann. Corn and Sorghum Ind. Res. Conf, Am. Seed Trade Assoc., Washington. 
